\title{
ВИВЧЕННЯ ПРОТИЗАПАЛЬНОЇ АКТИВНОСТІ СУХОГО ЕКСТРАКТУ 3 ЛИСТЯ САЛАТУ ПОСІВНОГО
}

Вступ. Проблема фрармакологічної корекції запалення, як і раніше, залишається актуальною, оскільки сучасна медицина повністю їі не вирішила. Одним із перспективних напрямів створення безпечних та есрективних протизапальних препаратів є фрітотерапія. В останні роки підвищився інтерес до препаратів рослинного походження.

Мета дослідження - вивчити протизапальну активність сухого екстракту з листя салату посівного в експерименті з модельованим карагеніновим набряком лапи щурів.

Методи дослідження. При визначенні протизапальної активності екстракту з листя салату посівного використовували безпородних білих щурів-самців масою 180-200 г. Індукцію гострого асептичного запалення проводили шляхом субплантарної ін'єкції 0,1 мл 1 \% розчину карагеніну. Досліджуваний зразок екстракту в дозі 100 мг/ке маси тіла вводили піддослідним щурам внутрішньошлунково у профрілактичному режимі одноразово за 1 год до індукції запалення. Через 1, 3, 6 та 24 год вимірювали об'єм здоровоі та ураженої кінцівок за допомогою механічного онкометра. Антиексудативну активність екстракту визначали за ступенем зменшення набряку в піддослідних тварин порівняно з контрольними та виражали у відсотках. Як препарат порівняння використовували диклофенак натрію в дозі 8 мг/ка.

Результати й обговорення. Встановлено, що у групі тварин, які отримували екстракт з листя салату посівного, максимальний позитивний вплив на розвиток набряку спостерігали через 3 год від початку запалення (31,22 \%), і тривав він до кінця експерименту. Через 24 год від початку розвитку запалення ефрект від застосування екстракту був дещо нижчим. Але найменш виражений його вплив на розвиток запалення відзначали через 1 год дослідження. Аналогічний вплив мав диклофренак натрію, щоправда значний ефект від його застосування проявився вже через 1 год від початку експерименту.

Висновок. Доведено виразну протизапальну активність сухого екстракту з листя салату посівного, який найбільш активно пригнічує розвиток набряку лапи щурів через 1 год запалення.

КЛЮЧОВІ СЛОВА: сухий екстракт з листя салату посівного; карагеніновий набряк; протизапальна дія; білі щури.

ВСТУП. Запалення є основним патогенетичним компонентом більшості захворювань різної етіології, а проблема його фрармакологічної корекції залишається актуальною і до кінця невирішеною проблемою сучасної медицини [1]. Відповідно до сучасних уявлень про патогенез запальних реакцій, одним із провідних механізмів ушкодження тканин є процес вільнорадикального окиснення. Тривала активація окисних процесів супроводжується розвитком синдрому ліпопероксидації, який полягає в ушкодженні мембранних ліпідів, порушенні ресинтезу АТФ, накопиченні продуктів пероксидного окиснення ліпідів і протеїнів. Надмірне утворення перекисів ліпідів порушує орізико-хімічну структуру мембран клітин, інгібує їх ензимні системи, інактивує цитоплазматичні ензими, знижує активність тіолових ензимів, що (с В. П. Пида, Л. С. Фіра, П. Г. Лихацький, 2018. призводить до розвитку альтеративних і ексудативних процесів у тканинах.

У медичній практиці широко використовують нестероїдні протизапальні засоби для лікування захворювань запального генезу. Механізм дії більшості таких препаратів пов'язаний зі здатністю пригнічувати синтез простагландинів шляхом блокади ензимів циклооксигенази (ЦОГ) обох типів: ЦОГ і ЦОГ ${ }_{2}$ [2]. Крім того, деякі нестероїдні протизапальні засоби інгібують утворення вільних радикалів, результатом чого є їх антиокиснювальна, антиоксидантна та мембраностабілізувальна дія [3]. Дані препарати мають велику кількість побічних ефектів, особливо 3 боку систем травлення та сечоутворення (ульцерогенна дія, бронхоспастичні реакції, пригнічення тканинного метаболізму тощо), що суттєво обмежує можливість їх застосування. 
Це робить актуальним пошук нових ефективних протизапальних засобів, особливо серед препаратів рослинного походження. Відомо, що фрітопрепарати мають ряд певних переваг над синтетичними лікарськими засобами, серед них - низька частота побічних ефектів, широкий вибір терапевтично активних інгредієнтів та можливість їх комбінованого використання.

Аналіз літератури дозволив встановити, що лікарські засоби природного походження чинять різнобічну комплексну дію на перебіг патологічних процесів в організмі $[4,5]$. Різні галенові препарати 3 офріцинальних рослин, а також відвари, настої, екстракти тощо, завдяки сумі діючих речовин, зумовлюють полімодальність есректів. Для більшості препаратів характерні добра переносимість, відсутність синдрому відміни та токсичності стосовно паренхіматозних органів [6]. Лікарські рослини застосовують не тільки як монопрепарати, але і як складні лікарські засоби, як сировину для подальшого синтезу есективних речовин.

При виборі об'єкту дослідження нашу увагу привернув салат посівний -популярна листова рослина, що застосовується в їжу та широко культивується. Сорт "Лолла Россо" характеризується значною врожайністю та гарними смаковими якостями [7].

Фітохімічні дослідження салату посівного провели науковці-фрітохіміки в напрямку вивчення френольних сполук, сесквітерпенових лактонів, хлоросрілів, каротиноїдів та макро- й мікроелементів [8].

Листя салату використовують для приготування різних страв. Салат покращує травлення, підвищує апетит, проявляє антиоксидантну, протизапальну, знеболювальну та інші види дії $[9,10]$.

Мета дослідження - вивчити протизапальну активність сухого екстракту з листя салату посівного в експерименті з модельованим карагеніновим набряком лапи щурів.

МЕТОДИ ДОСЛІДЖЕННЯ. Об'єкТом дослідження був сухий екстракт, який науковці НФаУ отримали з висушеної надземної частини салату посівного.

Протизапальну активність вивчали під час ексудативної фрази гострого асептичного запалення, яке було викликано шляхом субплантарного введення розчину карагеніну.

При визначенні протизапальної активності використовували безпородних білих щурів-самців масою 180-200 г. Індукцію гострого асептичного запалення проводили шляхом субплантарної ін'єкції 0,1 мл $1 \%$ розчину карагеніну $[11,12]$. Досліджуваний зразок екстракту в дозі 100 мг/кг маси тіла вводили піддослідним щурам внутрішньошлунково у профрілактичному режимі одноразово за 1 год до індукції запалення. Контрольним тваринам вводили відповідний об'єм води. Через 1 год після застосування екстракту під апоневроз задньої кінцівки щурів вводили 0,1 мл $1 \%$ розчину карагеніну. Через 1, 3, 6 та 24 год вимірювали об'єм здорової та ураженої кінцівок за допомогою механічного онкометра за О. С. Захаревським [13]. Величину набряку розраховували за різницею між об'ємами незапаленої та запаленої кінцівок. Антиексудативну активність екстракту визначали за ступенем зменшення набряку в піддослідних тварин порівняно $з$ контрольними та виражали у відсотках.

Як препарат порівняння використовували диклофренак натрію (інгібітор циклооксигенази) в дозі 8 мг/кг.

Усі дослідження проводили відповідно до Загальних етичних принципів експериментів на тваринах (Україна, 2001), які узгоджуються 3 положеннями Європейської конвенції про захист хребетних тварин, що використовуються для дослідних та інших наукових цілей (Страсбург, 1986) [14].

Статистичну обробку отриманих даних проводили за допомогою програми STATISTICA 6.0 3 використанням параметричного критерію Стьюдента. Зміни вважали вірогідними при $p<0,05[15]$.

РЕЗУЛЬТАТИ Й ОБГОВОРЕННЯ. ВИВчеННЯ протизапальної активності сухого екстракту 3 листя салату посівного показує, що в контрольній групі щурів, які отримували воду, розвиток запальної реакції спостерігали вже через 1 год від початку введення карагеніну, і максимуму він досягав через 3 год. У тварин цієї групи до 24 год експерименту набряк лапи зменшувався (табл.).

У групі тварин, які отримували екстракт 3 листя салату посівного, максимальний позитивний вплив на розвиток набряку спостерігали через 3 год від початку запалення (31,22 \%), і тривав він до кінця експерименту. Через 24 год від початку розвитку запалення ефект від застосування екстракту був дещо нижчим (на 9,79\%), ніж через 3 год експерименту. Найменший його вплив на набряк лапи щурів відзначали через 1 год від початку дослідження. У цей час ефективність екстракту проявилася лише на $11,30 \%$.

Аналогічний вплив мав диклофенак натрію, щоправда значний ефект від його застосування проявився вже через 1 год від початку експерименту.

Застосований референс-препарат "Диклофенак натрію" є еталонним протизапальним 


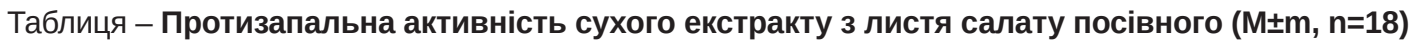

\begin{tabular}{|c|c|c|c|c|c|}
\hline \multirow{2}{*}{\multicolumn{2}{|c|}{ Група тварин }} & \multicolumn{4}{|c|}{ Динаміка розвитку запалення, год } \\
\hline & & 1 & 3 & 6 & 24 \\
\hline Контрольні тварини & $\Delta \mathrm{V}$ & $7,10 \pm 0,31$ & $9,45 \pm 0,59$ & $9,25 \pm 0,52$ & $7,70 \pm 0,42$ \\
\hline \multirow[t]{2}{*}{ Екстракт, 100 мг/кг } & $\Delta \mathrm{V}$ & $6,30 \pm 0,35$ & $6,50 \pm 0,50^{*}$ & $6,75 \pm 0,31^{*}$ & $6,05 \pm 0,21^{*}$ \\
\hline & Активність, \% & 11,30 & 31,22 & 27,03 & 21,43 \\
\hline \multirow{2}{*}{$\begin{array}{l}\text { Диклофенак натрію, } \\
8 \text { мг/кг }\end{array}$} & $\Delta \mathrm{V}$ & $5,20 \pm 0,15^{\star}$ & $5,95 \pm 0,38^{*}$ & $5,55 \pm 0,14^{*}$ & $5,15 \pm 0,10^{*}$ \\
\hline & Активність, \% & 26,76 & 37,04 & 40,00 & 33,12 \\
\hline
\end{tabular}

Примітки:

1. $\Delta \mathrm{V}$ - величина набряку.

2. * - відхилення показника вірогідне щодо контрольної групи $(p<0,05)$.

засобом. Його визнано стандартом за ефективністю та нешкідливістю серед нестероїдних протизапальних препаратів. Фармакологічні властивості диклофенаку натрію добре вивчено, зокрема механізм його дії базується на блокаді обидвох ізоферментів цОГ, більшою мірою ЦОГ-2. 3 аналізу літератури відомо, що, крім інгібування простагландинів, даний препарат може перешкоджати міграції лейкоцитів у вогнище запалення $[16,17]$. У патогенезі розвитку запального процесу на моделі карагенінового набряку в перші 30-90 хв беруть участь гістамін і серотонін, в інтервалі 1,5-2,5 год кініни, а в інтервалі 2,5-5,5 год - простагландини $[8,18]$.

На основі аналізу результатів наших досліджень можна вважати, що протизапальна активність сухого екстракту з листя салату посівного проявляється за рахунок блокади ЦОГ та впливу на медіатори запалення - простагландини.

ВИСНОВКИ. Результати проведених досліджень свідчать про виразну протизапальну дію сухого екстракту з листя салату посівного, який найбільш активно пригнічує розвиток набряку лапи щурів через 3 год запалення. Досліджуваний екстракт за наявності значної кількості біологічно активних речовин, імовірно, інгібує процеси утворення гістаміну, серотоніну та прозапальних цитокінів.

Досліджуваний екстракт з листя салату посівного сорту “Лолла Россо" можна рекомендувати для подальшого дослідження 3 метою створення на його основі нових лікарських засобів із протизапальною активністю з наступним запровадженням у лікарську практику.

\section{СПИСОК ЛІТЕРАТУРИ}

1. Фармакологічне вивчення протизапальної активності і гострої токсичності настойки складної "Атеросріт-норма" / К. О. Хохлова, Л.І.Вишневська, О. І. Набока, С. В. Гарна // Укр. мед. альм. -2012. -15, № 5. - С. 60-62.

2. Страчунский Л. С. Нестероидные противовоспалительные средства / Л. С. Страчунский, С. Н. Козлов. - Смоленск, 1997. - 70 с.

3. Tadić V. M. Anti-inflammatory, gastroprotective, free-radicalscavenging, and antimicrobial activities of hawthorn berries ethanol extract / V. M. Tadić, S. Dobrić, G. M. Marković // J. Agric. Food Chem. - 2008. - 56, No. 17. - P. 7700-7709.

4. Кортиков В. Н. Справочник лекарственных растений / В. Н. Кортиков, А. Н. Кортиков. - Ростовна-Дону : Издательский дом “Профр-Пресс", 2004. $800 \mathrm{c}$.

5. Khare C. P. Indian Medicinal Plants: An Illustrated Dictionary 2007th. Springer-Verlag New York, 2007. $900 \mathrm{p}$.

6. Kuete V. Medicinal Spices and Vegetables from Africa. London, Academia Press, 2017. - 669 p.
7. Лікарські рослини : енцикл. довід. / відп. ред. А. М. Гродзінський. -К. : Голов. ред. УРЕ, 1990. -544 с.

8. Araruna K. Anti-inflammatory activities of triterpene lactones from Lactuca sativa / K. Araruna, B. Carlos // Phytopharmacology. - 2010. - 1 (1). - P. 1-6.

9. Harsha S. N. Anxiolytic property of hydro-alcohol extract of Lactuca sativa and its effect on behavioral and biochemical activity / S. N. Harsha, K. R. Anilakumar // The Journal of Biomedical Research. - 2013. - 27 (1). P. 37-42.

10. Harsha S. N.Anxiolytic property of Lactuca sativa, effect on anxiety behavioral induced by novel food and height / S. N. Harsha, K. R. Anilakumar // Asian Pacific Journal of Tropical Medicine. - 2013. - P. 532-536.

11. Доклинические испытания лекарственных средств : метод. рек. / под ред. А. В. Стефранова. - К. : Авицена, 2002. - 568 с.

12. Di Rosa M. Studies on the mediators of the acute inflammatory response induced in rats in different siles by carrageenen and turpentine / M. Di Rosa, J. P. Giround, D. A. Villinghby // J. Pathol. -1971. - 104, No. 15. - P. 29. 
13. Захаревский А. С. Влияние некоторых производных индола на нервную систему (антагонисты серотонина) : дисс. ... канд. мед. наук / А. С. Захаревский. - Минск, 1962. - С. 78-80.

14. Gross D. Ethics in animal-based research / D. Gross, R. Tolba // Eur. Surg. Res. - 2015. - 55, Issue 1-2. - P. 43-57.

15. Основные методы статистической обработки результатов фрармакологических экспериментов : руководство по экспериментальному (доклиническому) изучению новых фрармакологических веществ / под ред. Р. Ю. Хабриева. - М. : Ремедиум, 2000. C. $349-354$.

\section{REFERENCES}

1. Khokhlova, K.O., Vyshnevska, L.I., Naboka, O.I., \& Harna, S.V. (2012). Farmakolohichne vyvchennia protyzapalnoi aktyvnosti i hostroi toksychnosti nastoiky skladnoi "Aterofit-norma" [Pharmacological study of antiinflammatory activity and acute toxicity of tincture of complex "Atherophyte-norm"]. Ukrainskyi medychnyi almanakh - Ukrainian Medical Almanac, 15 (5), 60-62 [in Ukrainian].

2. Strachunskiy, L.S., \& Kozlov, S.N. (1997). Nesteroidnyye protivovospalitelnyye sredstva [Non-steroidal anti-inflammatory drugs]. Smolensk [in Russian].

3. Tadić, V.M., DobrićS, \& Marković, G.M. (2008). Anti-inflammatory, gastroprotective, free-radicalscavenging, and antimicrobial activities of hawthorn berries ethanol extract. J. Agric. Food Chem., 56 (17),7700-7709.

4. Kortikov, V.N. (2004). Spravochnik lekarstvennykh rasteniy [Directory of medicinal plants]. Rostov na Donu: "Izdatelskiy dom Prof-Press" [in Russian].

5. Khare, C.P. (2007). Indian Medicinal Plants: An Illustrated Dictionary 2007th. Springer-Verlag New York.

6. Kuete, V. (2017). Medicinal spices and vegetables from Africa. London, Academia Press.

7. Hrodzinskyi, A.M. (1990). Likarski roslyny: Entsyklopedychnyi dovidnyk [Medicinal plants: Encyclopedic reference book]. Kyiv: URE [in Ukrainian].

8. Araruna, K., \& Carlos, B. (2010). Anti-inflammatory activities of triterpene lactones from Lactuca sativa. Phytopharmacology, 1 (1), 1-6.

9. Harsha, S.N., \&Anilakumar, K.R. (2013). Anxiolytic property of hydro-alcohol extract of Lactuca sativa and its effect on behavioral and biochemical activity. The Journal of Biomedical Research, 27 (1), 37-42.

10. Harsha, S.N. \& Anilakumar, K.R. (2013). Anxiolytic property of Lactuca sativa, effect on anxiety behavioral induced by novel food and height. Asian Pacific Journal of Tropical Medicine, 532-536.

11. Stefanov, A.V. (Ed.). (2002). Doklinicheskiye ispytaniya lekarstvennykh sredstv. Metodicheskiye
16. Головач І. Ю. Диклофенак натрію у терапії суглобового синдрому / І. Ю. Головач // Здоров'я України. - 2012. - 28 груд. - 57 с.

17. Дзяк Г. В. Нестероидные противовоспалительные средства: новые представления о механизме действия и новые возможности / Г. В. Дзяк // Лікування та діагностика. - 1997. - № 3. - С. 12-16.

18. Линда О. С. Вивчення протизапальної активності настойки та екстракту з листя хости ланцетолистої / О. С. Линда, Л. С. Фіра, П. Г. Лихацький // Укр. біофрармац. журн. - 2018. - № 2 (55). - С. 32-35.

rekomendatsii [Preclinical trials of medicines. Guidelines]. Kyiv: Avitsenna [in Ukrainian].

12. Di Rosa, M., Giround, J.P., \& Villinghby, D.A. (1971). Studies on the mediators of the acute inflammatory response induced in rats in different siles by carrageenen and turpentine. J. Pathol., 104, (15), 29.

13. Zakharevskiy, A.S. (1962). Vliyaniye nekotorykh proizvodnykh indola na nervnuyu sistemu (antagonisty serotonina) [Influence of some indole derivatives on the nervous system (serotonin antagonists)]. Candidate's thesis [in Russian].

14. Gross, D., \& Tolba, R. (2015). Ethics in animalbased research. Eur. Surg. Res, 55, (1-2), 43-57.

15. Khabriyeva, R.Yu. (2000). Osnovnyye metody statisticheskoy obrabotki rezultatov farmakologicheskikh eksperimentov: rukovodstvo po eksperimentalnomu (doklinicheskomu) izucheniyu novykh farmakologicheskikh veshchestv [The main methods of statistical processing of the results of pharmacological experiments: a guide to experimental (preclinical) study of new pharmacological substances]. Moscow: Remedium [in Russian].

16. Holovach, I.Yu. (2012). Dyklofenak natriiu u terapii suhlobovoho syndromu [Sodium diclofenac in the treatment of articular syndrome]. Zdorovia Ukrainy Health of Ukraine, 57 [in Ukrainian].

17. Dzyak, G.V. (1997). Nesteroidnyye protivospalitelnyye sredstva: novyye predstavleniya o mekhanizme deystviya i novyye vozmozhnosti [Non-steroidal antiinflammatory drugs: new ideas about the mechanism of action and new possibilities]. Likuvannia ta diahnostyka Treatment and Diagnosis, 3, 12-16 [in Ukrainian].

18. Lynda, O.S., Fira, L.S., \& Lykhatskyi, P.H. (2018). Vyvchennia protyzapalnoi aktyvnosti nastoiky ta ekstraktu z lystia khosty [Study of anti-inflammatory activity of tincture and extract from host leaves of lanceolate]. Ukr. biof. Zhurnal - Ukrainian Biopharmaceutical Journal, 2 (55), 32-35 [in Ukrainian]. 


\section{ИЗУЧЕНИЕ ПРОТИВОВОСПАЛИТЕЛЬНОЙ АКТИВНОСТИ СУХОГО ЭКСТРАКТА ИЗ ЛИСТЬЕВ САЛАТА ПОСЕВНОГО}

\section{Резюме}

Вступление. Проблема фрармакологической коррекции воспаления по-прежнему остается актуальной, поскольку полностью не решена современной медициной. Одним из перспективных направлений создания безопасных и эфроективных противовоспалительных препаратов является фритотерапия. $B$ последние годы повысился интерес к препаратам растительного происхождения.

Цель исследования - изучить противовоспалительную активность сухого экстракта из листьев салата посевного в эксперименте с моделируемым каррагениновым отеком лапы крыс.

Методы исследования. При определении противовоспалительной активности экстракта из листьев салата посевного использовали беспородных белых крыс-самцов массой 180-200 г. Индукцию острого асептического воспаления проводили путем субплантарной инъекции 0,1 мл 1 \% раствора каррагенина. Исследуемый образец экстракта в дозе 100 мг/кг массы тела вводили подопытным крысам внутрижелудочно в профрилактическом режиме однократно за 1 ч до индукции воспаления. Через 1, 3, 6 и 24 ч измеряли объем здоровой и пораженной конечностей с помощью механического онкометра. Антиэкссудативную активность экстракта определяли по степени уменьшения отека в подопытных животных по сравнению с контрольными и выражали в процентах. В качестве препарата сравнения использовали диклофренак натрия в дозе 8 мг/ке.

Результаты и обсуждение. Установлено, что в группе животных, получавших экстракт из листьев салата посевного, максимальное положительное влияние на развитие отека наблюдали через 34 от начала воспаления (31,22 \%), и продолжалось оно до конца эксперимента. Через 24 ч от начала развития воспаления эффрект от применения экстракта был несколько ниже. Но менее выраженное его влияние на развитие воспаления отмечали через 1 ч исследования. Аналогичное влияние имел диклофенак натрия, правда значительный эфрфект от его применения проявился уже через 1 ч от начала эксперимента.

Вывод. Доказана выразительная противовоспалительная активность сухого экстракта из листьев салата посевного, который наиболее активно подавляет развитие отека лапы крыс через 3 ч воспаления.

КЛЮЧЕВЫЕ СЛОВА: сухой экстракт из листьев салата посевного; каррагениновый отек; противовоспалительное действие; белые крысы.

\section{STUDY OF ANTI-INFLAMMATORY ACTIVITY OF DRY EXTRACT FROM LEAVES OF LACTUCA SATIVA}

\section{Summary}

Introduction. The problem of pharmacological correction of inflammation, is still relevant, because it is not completely solved by modern medicine. One of the promising areas for creating safe and effective anti-inflammatory drugs is phytotherapy. In recent years, interest has increased in preparations of plant origin.

The aim of the study - to learn the anti-inflammatory activity of the dry extract from the leaves of the planting cutting lettuce in an experiment with simulated carrageenan edema of the rat paws.

Research Methods. In determining the anti-inflammatory activity of the extract from the cutting lettuce leaves, mongrel white male rats weighing 180-200 grams were used. Induction of acute aseptic inflammation was carried out by subplantal injection of $0.1 \mathrm{ml}$ of a $1 \%$ solution of carragenan. The test sample of the extract at a dose of $100 \mathrm{mg} / \mathrm{kg}$ body weight was administered to experimental rats intragastrically in the preventive regimen once per 1 hour before the induction of inflammation. After 1, 3, 6 and 24 hours, the volume of the healthy and affected limb was measured using a mechanical on-line meter. The antiexudative activity of the extract was determined by the degree of edema reduction in the experimental animals as compared to the control animals and expressed as a percentage. As a reference, diclofenac sodium was used at a dose of $8 \mathrm{mg} / \mathrm{kg}$. 
Results and Discussion. We found out that in the group of animals that received the extract from the leaves of the cutting lettuce, the maximum positive effect on the development of edema was observed at 3 hours from the beginning of the filling (31.22\%) and continued until the end of the experiment. After 24 hours from the onset of inflammation, the effect of using the extract from the salad was slightly lower. But less pronounced influence on the development of inflammation was for 1 hour of study. A similar effect was shown by diclofenac sodium, although a significant effect from its use appeared already at the first hour from the beginning of the experiment.

Conclusion. The expressive anti-inflammatory activity of the dry extract from the cutting lettuce leaves is proved, which most actively suppresses the development of the paw edema on the third hour of inflammation.

KEY WORDS: dry extract from leaves of cutting lettuce; carragenan edema; anti-inflammatory effect; white rats.

Отримано 10.07.18

Адреса для листування: Л. С. Фіра, Тернопільський державний медичний університет імені І. Я. Горбачевського, майдан Волі, 1, Тернопіль, 46001, Україна, e-mail: fira@tdmu.edu.ua. 